\title{
Journal of Public Policy \& Governance
}

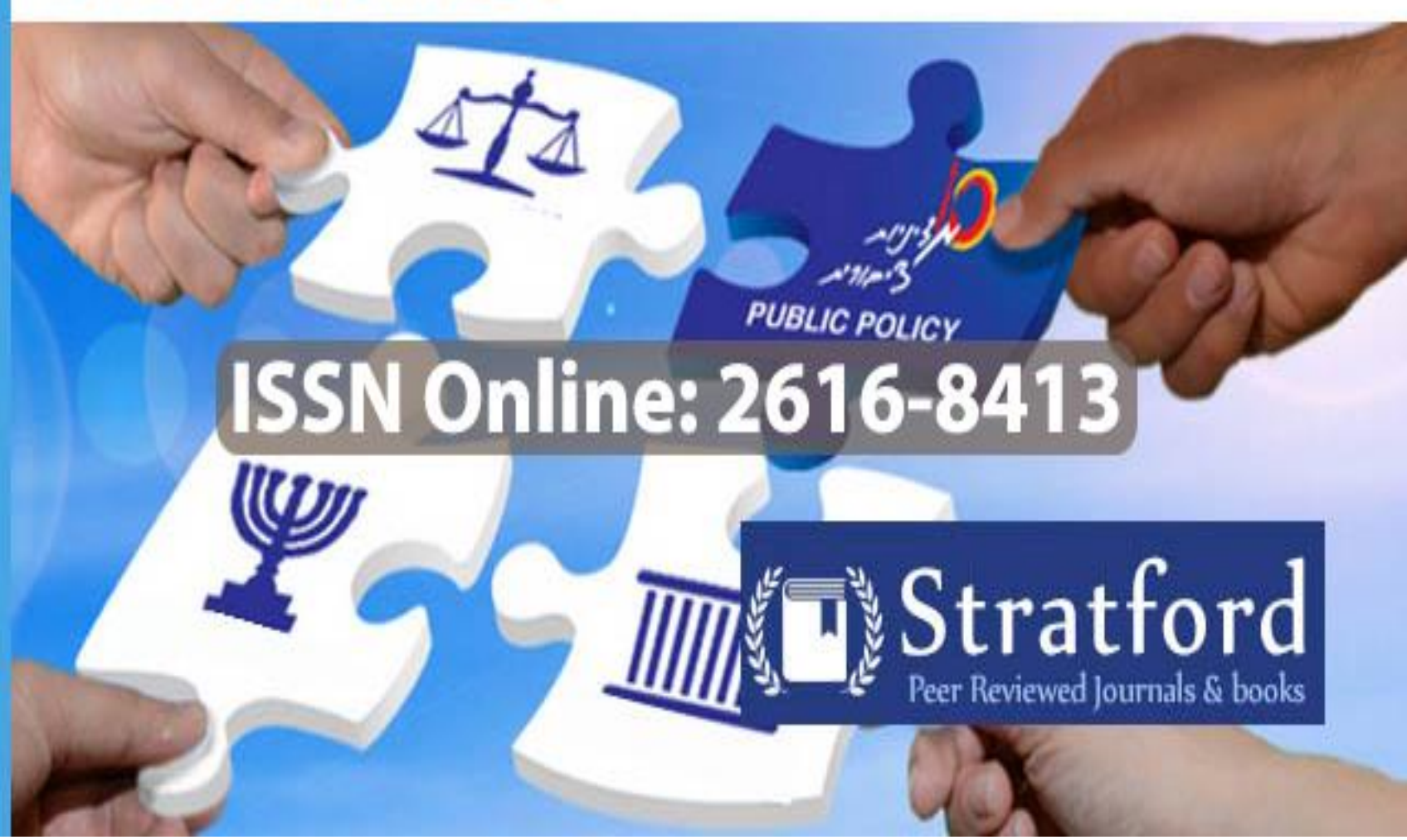

Resource and Stakeholder Mobilization by Community-Based Organizations for Community Economic Development in Kenya: A Survey of Community-Based Organizations in Siaya County

Herbert Barasa \& Juster Nyaga

ISSN: 2616-8413 


\title{
Resource and Stakeholder Mobilization by Community- Based Organizations for Community Economic Development in Kenya: A Survey of Community-Based Organizations in Siaya County
}

\author{
${ }^{1}$ Herbert Barasa \& ${ }^{2}$ Juster Nyaga \\ ${ }^{1}$ Graduate Student, School of Management and Leadership \\ Management University of Africa \\ ${ }^{2}$ Lecturer, School of Management and Leadership Management \\ University of Africa
}

Email of the Corresponding Author: barasa.hb@gmail.com

How to cite this article: Barasa, H. \& Nyaga, J. (2021). Resource and Stakeholder Mobilization by CommunityBased Organizations for Community Economic Development in Kenya: A Survey of Community-Based Organizations in Siaya County. Journal of Public Policy \& Governance. Vol 5(3) pp. 81-98. https://doi.org/10.53819/81018102t6001

\begin{abstract}
Most developing countries, including Kenya, have a big proportion of the population still living in rural areas that face an immense challenge especially on economic development and access to basic social infrastructure that include roads, health, water, and education. The government and local authorities are striving with the available limited resources against the competing priorities in order to meet the needs of the population and improve the quality of life and wellbeing. This study examined the role of community-based organizations (CBOs) on economic development in Siaya County, specifically their role on resource and stakeholder mobilization in Kenya. The study was anchored on Social Capital Theory but also analyzed both System and Conflict Theories. The study provides new and relevant information on the role of CBOs in development to the County governments as devolved systems of government responsible for development and planning thus justifying investment and policy formulation for closer collaboration. Descriptive study was undertaken and targeted and enumerated two respondents per group (total 50) in all the 25 CBOs in Siaya County that were duly registered and had coverage of at least one Sub-County. Using a Likert scale questionnaire, quantitative data was collected. Prior to that, a pilot study was done in the nearby Kakamega County to test the instrument. Descriptive, correlation and regression analysis was applied to the data using SPSS version 21. The findings indicate that; Resource Mobilization by CBOs enhances the organizations' contribution to community economic development, stakeholders' mobilization plays a critical role in community economic development, the CBOs in Siaya County have managed to increase their impact on economic
\end{abstract}


development at the community level. The study suggests replication in other counties where NGO activity is evident in Kenya, focusing on community based organizations that do not rely on aid as their main income sources. Moreover, a comparative study involving the CBOs from the East African countries should also be considered in future studies.

Keywords: Resource Mobilization, Stakeholder Engagement, community based organization and Siaya County.

\subsection{Introduction}

History of community-based organizations (CBOs) can be traced to the American Civil War, where their role was to offer assistance to the people that were displaced, impoverished, and disabled during the war. The CBOs grew faster in the 1980s and 1990s and were commonly referred to as a movement. The major role of these organizations was to mobilize resources and people towards meeting common objectives of the members. In Africa, CBOs have been very important sources of development especially for the rural and urban poor. Tirivanhu (2020) notes that this is partly due to the poor performance by local government institutions in delivery of services that has contributed to their proliferation in many African countries. They have therefore been used as a sign of self-determination by communities in efforts to drive local development in the areas in which they operate. These organizations represent the poor with a common identity to advocate for their rights but most significantly to mobilize local resources for social and economic development. In Nigeria, CBOs have allowed poor households and poor communities to move from isolation and powerlessness into collective strengths and have become powerful development mechanisms. For instance, Akeju et al. (2021) find that long-standing CBOs in Nigeria had built up strong organizational capacities and infrastructure that positively influences services planning in the health sector. In Ghana, CBOs have for long periods of time provided water, sanitation and hygiene (Dodoo \& Kisii, 2021), health planning services (Woods et al., 2021), and participated in government funded projects that spur development (Boadi \& Badu, 2021). In Rwanda, they are important partners in planning and for the success of rural development projects (Laurent \& Ernest, 2021). The burgeoning evidence of the role of CBOs, is thus an indicator of the vital role that they play across various sectors to spur multifaceted development across various sectors.

In Kenya, CBOs play a key role in promoting both rural and urban development and have the power to influence policy and community development initiatives. They are powerful tools for nutrition programs for infants and related health practices (Mapesa, Meme \& Muthamia, 2020), tourism development projects (Murungi, 2020), water projects (Mwaura et al., 2020), livestock farming (Ojango et al., 2021), sustainable enterprise and resource development (Prieto et al, 2021) among other development programmes and projects. The ambit of their role in development programmes is therefore diverse, which has also seen a burgeoning number of CBO led programmes and projects across different areas of the country.

Organizational Resource Mobilization (RM) strategies are designed to obtain additional resources and to make optimal use of those that are already in possession. Batti (2014) demonstrates that $\mathrm{RM}$ is an important component of building a stronger company. As competition for limited resources grows, finding and implementing alternative financing methods can make it easier for an organization to manage its initiatives, resulting in more sustainable programs. An organization's financial resources can be expanded by generating resources through its commercial operations. 
Sustainability may be compromised by insufficient funding for project implementation (Bamberger \& Cheema, 2010). Resources play a vital role in the survival and success of CBOs. Evidence indicates that through cultivating resources, CBOs have a clearer path to survival in the communities in which they operate (Walker \& McCarthy, 2014). Resources mobilization also serves as an important component of economic development because it is critical to providing the necessary resources that are needed for interventions (Johansson et al., 2009). It thus becomes vital for CBOs to mobilize adequate resources in order to ensure that their operations and activities are well funded.

Stakeholder Mobilization and engagement involves the ability of an organization to create collaborative relationships with a wide number of stakeholders. It includes a set of practices and initiatives that an organization develops to positively engage with various stakeholders in the activities carried out by the organization (Sulkowski et al., 2018). When stakeholders are engaged properly, they are more likely to collaborate and support the activities of an organization, and this positively impacts its sustainability and evolution (Freeman, 2017). Therefore it is prudent for an organization to manage the relationship with stakeholders and engage them to ensure that they succeed in their activities (Campra et al., 2020). This is particularly true for community based organizations that often must work in close collaboration with a set of various stakeholders.

\subsection{Statement of the Problem}

If large portions of a community remain living in abject poverty, then no society can achieve the level of social cohesiveness anticipated by Kenya Vision 2030 of investing in high-poverty incident areas; youth unemployment, women, and other vulnerable population special focus. Forty percent of Kenyans live in extreme poverty (World Bank, 2020). Siaya Human Development Index is estimated to be at 0.46 against the national average of 0.56 (Siaya CIDP, 2018-2022). SDG 1 calls for thriving lives and livelihoods, eradicating poverty, and enhancing wellbeing via access to education, work, and information, as well as improved health and housing, and reducing inequality.

Siaya County Integrated Development Plan (2018-2022), indicated that numerous communitybased groups have been inactive due to the inability to maintain their initiatives over time. As a result, efforts have been undertaken to develop the ability of the groups to revitalize these initiatives. In order to enable the groups to engage in development activities, loans and grants were made available to them. Since most community-based groups' programs are not sustainable, poverty reduction remains an issue (Siaya CIDP, 2018-2022). Siaya County CBO initiatives have failed to meet sustainability review requirements. Over 25 CBO initiatives were launched in 2019 and less than 10 projects were still active at the end of the year (Siaya CIDP, 2018-2022).

Researchers have highlighted financial planning, partnership functioning, and environmental effect as variables impacting the sustainability of community-based organization initiatives (Kanyanya, 2014; Macharia, 2015), as well as inadequate financial reporting (Batti, 2014). The function of community-based groups in economic growth among Kenyan counties, on the other hand, has not been examined fully by studies. Accordingly, the current study investigated Community Based Organizations in Siaya County.

\subsection{Objectives of the Study}

To determine the role of community based organization in resource and Mobilization and its effect on economic development in Siaya County. 


\subsection{Literature Review}

\subsection{Theoretical Literature Review Social Capital Theory}

Social capital theory was first conceptualized by Bourdieu (1986) as a source of benefit derived from social connections. Coleman (1988) saw social capital as essentially residing in the social structure of relationships among people. In the view of Machalek and Martin (2015), social interactions are resources that can contribute to the growth and accumulation of human capital. Solidarity and the effectiveness of community activities are dependent on the strength of social interactions. Mutual respect, trust, and a willingness to share resources are essential components of collaborative action in order to be successful. These ties are viewed by social scientists as a type of "capital." Associative capital comprises trust, standards, and networks. Confidence in political institutions, civic involvement, self-sufficient economic development, and general communal well-being and enjoyment are all often linked with this concept. Everyday connections are characterized by a high degree of trust. Since it spans beyond political, economic, and cultural divides, equality is viewed as a fundamental cultural ideal that is rich in social capital. Cultural norms such as reciprocity are also regarded to be part of social capital.

Reciprocity is fostered when people and communities provide food banks, scholarship money, and low-cost housing, as well as various kinds of self-help, mutual aid, and emotional support. This can make it simpler for community development efforts to arise when there is a high degree of reciprocity in the culture. It has been argued by critics of this idea that societies with high social capital may also generate intolerance and arrogance.

There is "bonded social capital" and "bridge social capital," according to the authors. The focus should be on "bridging social capital" - the development of new social links and contacts to extend networks and give a wider range of new leaders with fresh ideas and information. AfricanAmerican and Caucasian faith-based communities, for example, have been strengthened in certain places and leadership programs that develop emerging and varied groups of leaders have been formed. In addition to establishing new community links to wider resource bases, these activities also help to foster new levels of trust, reciprocity, and other norms among participants. People may get to know one other and create trust through common hobbies such as music, book groups, gaming, or other pastimes according to social capital theory. To flourish and improve their quality of life, some communities may have a high level of social capital for bonding, but they may also require "bridging social capital".

\subsection{Empirical Literature Review}

\section{Resource Mobilization and Economic Development}

Velazquez (2021) examines resource mobilization through the COVID-19 pandemic among community based organizations in New Jersey. The study utilized an already existing social field created by Paterson Alliance- an organization that focuses on community based organizations together. The study established that the CBOs involved altered their resource mobilization strategies as response measures to the COVID-19 pandemic. Specifically, CBOs banded together and restructured their finances to ensure effective distribution of information and mobilized resources including food and personal care items for community members that were in need. The 
connections and collaborations that were made through the community field were required to remain focal points to ensure comprehensive and effective recovery in the post-pandemic era. Fole, Lixia and Guta (2018) examined the importance of resource mobilization skills as integral parts to survival of non-governmental organizations in Malawi. The study, a qualitative approach targeted respondents from 12 NGOs, from which 72 respondents were selected. Primary data collection was collected using focus group discussions, key informant interviews, survey and observations. Qualitative data was analyzed thematically and quantitative data was analyzed using descriptive statistics. Findings from the analysis showed that resource mobilization and technical knowhow by managers affected the survival of local NGOs. Resource mobilization strategies were found to be essential to the ability of NGOs to source sufficient funds to fund projects and programmes.

Ihejirika and Ogbugo (2018) studied the influence of resource mobilization on community development projects in River State in Nigeria. Specifically, the study looks at the intervening role of traditional leaders on resource mobilization by examining how they organize, mobilize and utilize human and material resources for community development projects to economically develop the State. The study used a descriptive research design and surveyed 133 respondents. Statistical analysis of the data included ANOVA. The findings established that community members (specifically traditional leaders) mobilized resources through various fund raising programmes to ensure CBOs effectively implement their community development programmes. This included negotiating for tangible resources such as land, and organizing community participation/human resources to ensure project success.

Behnke et al. (2017) examine resource mobilization for CBOs dealing with rural water systems in Ghana, Kenya and Zambia. The study used interviews, focus group discussions and mapping activities in 18 rural communities across the three countries. The findings indicate that several non-monetary and non-fee mechanisms of resource mobilization that included mobilization of personal and communal assets, institutions and labour for water projects. The findings reveal that committees in these organizations use these mechanisms to mobilize resources to fund their operations, maintenance, repairs and upgrades for the projects that they engaged in.

John, Muturi and Nyang'au (2017) investigate effects of resource mobilization on strategies adopted by community based organizations in Nyamira County, Kenya. The study targeted nine hundred and fifteen social development officers, and community based organization members. Data analysis used descriptive statistics that included Chi square and logistic regression. The findings of the study concluded that resource mobilization influenced strategy adoption by community based organizations. The study recommends using appropriate resource mobilization strategies for effective community based organizational programmes.

\section{Stakeholder Mobilization and Economic Development}

Di Maddaloni and Davis (2018) looked at the perceptions of managers in local communities stakeholder megaprojects in the United Kingdom. The study was exploratory and used thematic and cluster analysis to investigate how local communities' stakeholder is perceived. The study was done in the view that stakeholder management is an essential part that maximizes positive inputs and minimizes negative attitudes through taking into account the needs and requirements for all project stakeholders. The study found that current project stakeholder management mechanisms were reactive rather than proactive and mainly offered an instrumental perspective. The study 
therefore recommends a broader inclusiveness of secondary stakeholders in local communities in community projects to ensure that they are successfully implemented.

Brunton et al. (2017) examine the narratives of stakeholder-community engagement for public health interventions. The study systematically reviewed public health interventions using stakeholder involvement. Data was thematically analyzed. A meta-analysis was also done. The findings indicated that involving communities as stakeholders has a positive effect on building commitment to the promotion of public health and can empower the public and local communities to advocate for change. The involvement of stakeholders was therefore seen as an integral part affecting public health interventions for local communities.

Using a survey of local government institutions in Punjab, Pakistan, Rafique and Khoo (2018) investigated the role of community-based organizations (CBOs) in fostering public engagement. The study's goal was to determine if CBOs in Punjab were effective in promoting active citizenship in local government decision-making. Survey items, both open and closed-ended, were included in the self-administered questionnaire. CBO members and local government officials filled out a total of 424 questionnaires. Data were analyzed using standard survey procedures, such as frequency distribution and comparative analyses. According to the report, CBOs are not particularly effective in educating all stakeholders and the general public, or at incorporating public demands and values into local government decision-making. According to the report, there is a need for more $\mathrm{CBO}$ education programs, enhanced public awareness efforts, and adequate procedures for incorporating and evaluating the requirements of the public.

Civera, De Colle and Casalegno (2019) applied the stakeholder theory to investigate forms of stakeholder engagement with small scale farmers in the coffee sector. The study put farmers at the center of a relationship network with all other supply chain stakeholders. Primary data was gathered using interviews with NGO representatives and coffee managers. The findings supported the identification of issues and needs on the relationship between farmers and other stakeholders. The study provided insights on how organizations can design empowerment strategies that lead to more effective stakeholder engagement and how these actions contribute to making low-power stakeholders engage more with an organization.

Papageorgiou et al. (2019) examine stakeholder involvement for social economic development for rural communities in Spain. The study used ordered weighted averaging in a case study involving poverty eradication and social-economic development strategies in rural communities in India. A positive causal relationship was established between involvement of stakeholders and sustainable socio-economic development strategies. Findings recommend policy makers to involve stakeholders in community projects to create social resilience and sustainable social-economic strategies.

Bowen (2009) examined local-level driven stakeholder collaboration and its effect on community driven development in Jamaica. The study used multiple sources of data and used qualitative data analysis in a grounded theory approach. Results from the analysis revealed that social fund community intervention was part of the process of development-focused collaboration among the various stakeholders. Stakeholder involvement in community development was found to involve four stages namely; problem identification, motivation and mobilization, closely working together and coating enabling environments for stakeholder involvement that ensures collaboration. Through this, a higher level of productivity in use of resources creates the atmosphere for community driven development.

https://doi.org/10.53819/81018102t6001 
Using data from Kenya, Mutua (2014) examined the influence of stakeholder mobilization at different phases of the community's life cycle for community-based initiatives' sustainability. He focused in particular on the sustainability of community water projects in Kaibaibate, Meru County, as a result of stakeholder involvement in design, management and assessment. As a result of the study, it was determined that community engagement is essential to the viability of community-based programs. As a result of supplying labor and a portion of costs and other resources, the community affects administrative structures. This means that they should continue to provide critical resources to a project and preserve the goodwill of the members. The members of the committee should be accountable and open in their actions.

Reading through literature and past studies it's noted that stakeholders and public mobilization to ensure collective participation is key to the success of projects (Rafique \& Khoo, 2018). Participation of the community and stakeholders in planning is also considered vital by the World Bank (2015).

Table 1: Summary of the Knowledge Gaps

\begin{tabular}{|c|c|c|c|c|c|}
\hline Author(s) & Year & Title of Study & Finding & Gap & Remarks \\
\hline Githinji, & 2019 & $\begin{array}{l}\text { A case study of } \\
\text { Isiolo North Sub } \\
\text { County, Isiolo } \\
\text { County, Kenya }\end{array}$ & $\begin{array}{l}\text { An analysis of factors } \\
\text { impacting sustainability } \\
\text { indicated that financing, } \\
\text { capacity building and } \\
\text { project implementers were } \\
\text { essential. }\end{array}$ & $\begin{array}{l}\text { However, the } \\
\text { present research } \\
\text { was done in } \\
\text { Siaya County } \\
\text { instead of Isiolo } \\
\text { County. }\end{array}$ & $\begin{array}{l}\text { Resources should be } \\
\text { identified by project } \\
\text { managers who have } \\
\text { the technical } \\
\text { competence to do so }\end{array}$ \\
\hline $\begin{array}{l}\text { Rafique \& } \\
\text { Khoo }\end{array}$ & 2018 & $\begin{array}{l}\text { Local government } \\
\text { institutions in } \\
\text { Punjab, Pakistan, } \\
\text { and the role of } \\
\text { community-based } \\
\text { organizations } \\
\text { (CBOs) in fostering } \\
\text { public involvement. }\end{array}$ & $\begin{array}{l}\text { According to the report, } \\
\text { CBOs are not particularly } \\
\text { effective in educating all } \\
\text { stakeholders and the } \\
\text { general public, or at } \\
\text { incorporating public } \\
\text { demands and values into } \\
\text { local government decision } \\
\text { making. }\end{array}$ & $\begin{array}{l}\text { The study was } \\
\text { carried out in } \\
\text { Punjab, } \\
\text { Pakistan while } \\
\text { the current } \\
\text { study was } \\
\text { carried out at } \\
\text { Siaya County, } \\
\text { Kenya }\end{array}$ & $\begin{array}{l}\text { Further education } \\
\text { programs for non- } \\
\text { profit organizations } \\
\text { are needed, as are } \\
\text { enhanced public } \\
\text { awareness efforts and } \\
\text { adequate procedures } \\
\text { to absorb and assess } \\
\text { public concerns. }\end{array}$ \\
\hline
\end{tabular}

\subsection{Conceptual Framework}

The conceptual framework shows graphically the relationship between the dependent and independent variables. Economic development by CBOs depends on effective resource mobilization and stakeholder mobilization strategies.

Independent variables

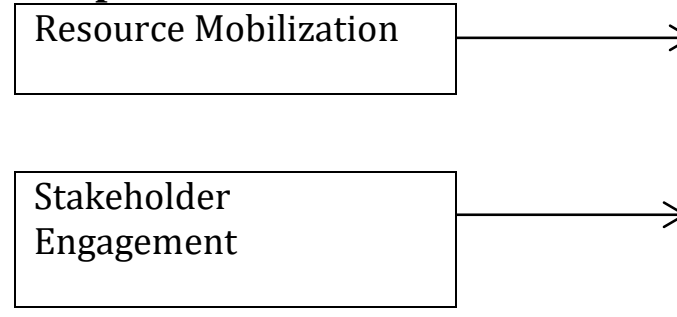

Dependent variables

Economic Development

Figure 1: Conceptual Framework 
Stratford Peer Reviewed Journals and Book Publishing

Journal of Public Policy \& Governance

Volume 5||Issue 3||Page 81-98 ||November||2021|

Email: info@stratfordjournals.org ISSN: 2616-8413

Table 2: Operationalization of Variable

\begin{tabular}{|c|c|c|c|}
\hline Variable & $\begin{array}{l}\text { Type of } \\
\text { variable }\end{array}$ & Indicator & $\begin{array}{l}\text { Measurement's } \\
\text { scale }\end{array}$ \\
\hline $\begin{array}{l}\text { Resource } \\
\text { mobilization }\end{array}$ & Independent & $\begin{array}{ll}\text { - } & \text { Financial management } \\
\text { - } & \text { Continuous funds inflow } \\
\text { - } & \text { Local donations } \\
\text { - } & \text { Local resources availability } \\
\text { - } & \text { Resource mobilization plan } \\
\end{array}$ & $\begin{array}{l}\text { Ordinal } \\
\text { Interval }\end{array}$ \\
\hline $\begin{array}{l}\text { Stakeholder } \\
\text { Engagement }\end{array}$ & Independent & $\begin{array}{l}\text { - Stakeholder mobilization plan } \\
\text { - Organization ownership } \\
\text { - } \quad \text { Minutes of stakeholders' meetings }\end{array}$ & $\begin{array}{l}\text { Ordinal } \\
\text { Interval }\end{array}$ \\
\hline $\begin{array}{l}\text { Economic } \\
\text { development }\end{array}$ & Dependent & $\begin{array}{ll}\text { - } & \text { Financial Stability } \\
\text { - } & \text { Viable economic activities } \\
\text { - } & \text { Partnerships for growth and innovation } \\
\text { - } & \text { Capacity empowerment initiatives }\end{array}$ & $\begin{array}{l}\text { Ordinal } \\
\text { Interval }\end{array}$ \\
\hline
\end{tabular}

\subsection{Methodology}

Research design is an overarching approach that a researcher uses to combine all of the study's elements Kothari (2014), to ensure that the study has addressed the research topic. A Descriptive research approach was adopted in this study. The study design was appropriate to obtain information about the current roles of CBOs in community economic development and gave a description of "what exists" regarding the different variables that were under analysis. The study focused on CBOs within the six sub-counties of Siaya County. According to the County Department of Social services 2020, there were 25 CBOs in Siaya County; duly registered and implementing economic development programmes with a minimum coverage of a sub-County. These CBOs were targeted in this study. Through a non-probability sampling strategy Fifty (two per $\mathrm{CBO}$ ) respondents were selected and included an official and a member to give the different perspectives and experiences at those levels. Questionnaires were the preferred primary data collection tool for the investigation and were administered to respondents. The questionnaire had responses on the Likert scale. The questionnaire data collection tool was submitted for approval by the University before the commencement of data collection.

Pilot research, according to Newing (2011), is crucial because it highlights concerns that individuals may have overlooked during the planning stage, allowing for useful data to be obtained throughout the study. Pre-testing of the tool was conducted on ten percent of the sample, on CBOs in Kakamega County, a neighboring non-sampled region. An updated version of the pre-tested tool was used for the actual data collection. A quantitative data analysis approach was employed to analyze the study's data. This included utilizing descriptive and inferential (correlation and regression) data analysis using SPSS version 21. Resource, stakeholder mobilization and economic development were tested using multiple linear regression. A diagram of the multiple regression model is shown below.

$Y=\beta_{0}+\beta_{1} X_{1}+\beta_{2} X_{2}+e$

Where:

$\mathrm{Y}=$ Economic Development 
$\mathrm{X}_{1}=$ Resource Mobilization

$\mathrm{X}_{2}=$ Stakeholder Mobilization

$\beta 0$ represents the constant

$\beta_{1}, \beta_{2}$, are regression coefficients

$\mathrm{e}$ is error term

\subsection{Findings}

\subsection{Response Rate}

A total of 50 questionnaires were administered and returned by the respondents representing a response rate of $100 \%$. However, out of all the questionnaires which were returned, three questionnaires were found to be incomplete and therefore were not used in the data analysis. As a result, the discussion of the study findings was based on submissions from 47 respondents from Siaya County, Kenya.

\subsection{Demographic Characteristics}

According to the findings, the respondents were fairly distributed in terms of gender $53.2 \%$ were male while $46.8 \%$ were female. Most (66\%) of the CBO members and officials, fall within the age bracket of 31-40 years, which is generally youthful, $23.4 \%$ of the respondents are aged between 41-50 years while very few $(2.1 \%)$ of the respondents are 50 or more years old while a small number (8.5\%) of them are aged between 21-30 years. The finding thus calls for a participation of young people in the activities of CBO organizations or an investigation as to why there are so few youth that are involved in CBO activities in Siaya County. Majority of the respondents are (40.4\%) diploma holders and $(42.6 \%)$ KCSE certificate holders while a few (17\%) of the respondents have other qualifications. Very few (6.4\%) of the respondents indicated that they had less than 5 years of $\mathrm{CBO}$ experience while $25.5 \%$ of the respondents had served CBOs for a period ranging from 6 to 10 years. The results also show that the majority (46.8\%) of the respondents had an experience of between 11-15 years while 21.3\% of them had CBO experience of between 16-20 years. Based on this finding, a majority of the respondents that participated in the study had worked long enough and had adequate experience. This enabled them to provide rich data, and have a higher level of comprehension of the questions in the data collection tool. Most $(61.7 \%)$ of the respondents reported that their CBOs consisted of more than 40 members followed by $19.1 \%$ of the respondents who indicated that their CBOs are made up of between 31-40 members. The statistics further show that fewer CBOs in Siaya County have relatively few members as demonstrated by $10.6 \%$ of the respondents who said their CBOs consist of $11-20$ members as $8.5 \%$ of the respondents opined that their organizations have between 21-30 members. Most of the CBOs were established in pursuit of advocacy objectives as depicted by $55.3 \%$ of the respondents. In addition, $23.4 \%$ of the respondents held the view that the CBOs were established to address economic development, $12.8 \%$ of the respondents reported that the organizations purpose was to address environmental conservation while a few (8.5\%) of the responses said the CBOs were established to serve healthrelated purposes. The findings therefore indicate that the $\mathrm{CBO}$ s in the study area performed a wide range of functions on top of economic development. 


\subsection{Descriptive Statistics}

According to the findings most (93.6\%) of the CBOs required finances while very few (4.3\% and $2.1 \%$ ) respondents prioritized human resources and capacity to undertake projects respectively as the most critical resources for their CBOs. Members' contributions in the CBOs constitute the primary source of $\mathrm{CBO}$ resources followed by funding by local CBOs and NGOs. This is the opinion held by about $51.1 \%$ and $34.0 \%$ of the respondents respectively. In addition, $14.9 \%$ of the respondents also indicated that their organizations rely on sponsorships and donor funding.

Many (97.9\%) members and officials of the CBOs perceive their organizations to be involved in networking and linkages and very few (2.1\%) do proposal development in order to mobilize resources for their respective community based organizations. This implies that most of the CBO resources are mobilized and sourced from the $\mathrm{CBO}$ networks and established linkages.

Table 3: Resource mobilization and community economic Development

\begin{tabular}{|c|c|c|c|c|c|}
\hline & $\mathbf{N}$ & Minimum & Maximum & Mean & $\begin{array}{c}\text { Std. } \\
\text { Deviation }\end{array}$ \\
\hline $\begin{array}{l}\text { My CBO play a major role in resource } \\
\text { mobilization for economic development in Siaya } \\
\text { County }\end{array}$ & 47 & 2 & 5 & 3.83 & .637 \\
\hline $\begin{array}{l}\text { My CBO has adequate resources to effectively } \\
\text { run its operations to ensure economic } \\
\text { development }\end{array}$ & 47 & 2 & 4 & 3.68 & .594 \\
\hline $\begin{array}{l}\text { My CBO has enough capacity to develop quality } \\
\text { proposals for to attract resources }\end{array}$ & 47 & 2 & 5 & 3.74 & .530 \\
\hline $\begin{array}{l}\text { My CBO has developed relationships with } \\
\text { different institutions to enable effective resource } \\
\text { mobilization }\end{array}$ & 47 & 3 & 5 & 4.64 & .529 \\
\hline $\begin{array}{l}\text { My CBO has capacity to advocate for resources } \\
\text { especially the government devolved funds }\end{array}$ & 47 & 2 & 5 & 3.89 & .634 \\
\hline
\end{tabular}

The results above show the respondents opinion on the relationship between resource mobilization and community economic development in Siaya County. According to the respondents' views (mean $=3.83$; Std Dev $=0.637$ ), the CBOs play a major role in resource mobilization for economic development. These findings concur with the results of Collins and James (2018) in which the study underscored the role of women in resource mobilization and recommended training on successful resource mobilization approaches to the community based groups. Whereas many respondents agreed (mean $=3.68$; Std Dev $=0.594$ ) that their CBOs had adequate resources to effectively operate to ensure economic development some of the CBOs were reported to have short supply of resources. In addition, the respondents indicated (mean $=3.74$; Std Dev $=0.530$ ) that their $\mathrm{CBO}$ had enough capacity to develop quality proposals to attract resources and also concurred (mean $=4.64 ;$ Std Dev $=0.529)$ that their organizations have developed relationships with different institutions to permit effective resource mobilization. Moreover, the CBO members and officials who participated in the study held the view (mean $=3.89$; Std Dev $=0.634$ ) that they have capacity to advocate for resources, especially the government devolved funds. 
According to the majority (80.9\%) respondents, community members are the main stakeholders for economic development while fewer (19.1\%) community leaders play some roles in economic development. The result indicated that resource mobilization is the main role of stakeholders in the CBOs in Siaya County as demonstrated by $91.5 \%$ of the respondents. However, the management of the CBOs in Siaya County is perceived to be a minor role as suggested by only $8.5 \%$ of the members and officials of the CBOs who took part in the study.

\section{Table 4: Stakeholder Mobilization and Community Economic Development}

\begin{tabular}{|c|c|c|c|c|c|}
\hline & $\mathbf{N}$ & Minimum & Maximum & Mean & Std. Deviation \\
\hline $\begin{array}{l}\text { Stakeholders are important to my CBOs } \\
\text { undertaking economic development }\end{array}$ & 47 & 3 & 5 & 4.40 & .577 \\
\hline $\begin{array}{l}\text { Proper identification of stakeholders has } \\
\text { enabled my CBO to be easily accepted in } \\
\text { the community }\end{array}$ & 47 & 4 & 5 & 4.77 & . 428 \\
\hline $\begin{array}{l}\text { Stakeholder mobilization has ensured } \\
\text { inclusivity of the different groups in } \\
\text { economic development }\end{array}$ & 47 & 4 & 5 & 4.62 & .491 \\
\hline $\begin{array}{l}\text { Stakeholder mobilization has enabled my } \\
\text { CBO to identify and utilize available } \\
\text { human resources in the community. }\end{array}$ & 47 & 4 & 5 & 4.70 & .462 \\
\hline $\begin{array}{l}\text { Stakeholder mobilization has ensure my } \\
\text { CBO can easily resolve conflict among the } \\
\text { community on economic development }\end{array}$ & 47 & 4 & 5 & 4.64 & .486 \\
\hline
\end{tabular}

The findings of the study presented above reveal that the respondents strongly agreed (mean $=$ 4.40; Std Dev $=0.577$ ) that stakeholders are important to my CBOs undertaking economic development and also concurred (mean $=4.77$; Std Dev $=0.4 .28$ ) that their CBOS have been accepted in their respective communities because they properly identified stakeholders. These findings differ from those of Punjab, Pakistan, Rafique, and Khoo (2018) study which indicated that in most projects the locals are hardly sensitized and are oftentimes not involved in all the stages of such interventions. This current study, however, clarifies the views of the respondents from Siaya County pointing out the rationale for community engagement, incorporation of the community interests and views as well as the importance of enlisting input from diverse stakeholders. In addition, the participants also reported $($ mean $=4.62$; Std Dev $=0.491$ ) that through stakeholder mobilization, they have managed to ensure inclusivity of the different groups in economic development activities and further agreed strongly (mean $=4.70 ; \mathrm{Std} \operatorname{Dev}=0.462$ ) that stakeholder mobilization has enabled their CBOs to identify and utilize available human resource in the community. The study also established (mean $=4.64$; Std Dev $=0.486$ ) through stakeholder mobilization, the CBOs in Siaya County can easily resolve conflict on economic development among the community members. 
Stratford Peer Reviewed Journals and Book Publishing

Journal of Public Policy \& Governance

Volume 5||Issue 3||Page 81-98 ||November||2021|

Email: info@stratfordjournals.org ISSN: 2616-8413

Table 5: Correlation Analysis

\begin{tabular}{llc}
\hline Variable & & Economic Development \\
\hline Resource Mobilization & Pearson Correlation & .256 \\
& Sig. (2-tailed) & .008 \\
Stakeholder Mobilization & N & 47 \\
& Pearson Correlation & .264 \\
& Sig. (2-tailed) & .000 \\
& N & 47
\end{tabular}

Table 5 shows a positive and statistically significant relationship $(r=0.256$; $\mathrm{Sig}=0.008)$ between the Resource Mobilization by CBOs in Siaya County and their contribution to community economic development. This implies that resource mobilization by the CBOs enhances the community's economic development. The study also indicated a positive and statistically significant correlation $(r=0.264$; Sig $=0.000)$ between stakeholder mobilization and community economic development which implies that enhanced stakeholder mobilization in community activities contributes to economic development.

\subsection{Regression Analysis}

Regression analysis was used to model the relationship between resource mobilization, stakeholder Engagement and community economic development.

Table 6: Regression Model Summary

\begin{tabular}{lcccc}
\hline Model & R & R Square & Adjusted R Square & $\begin{array}{c}\text { Std. Error of the } \\
\text { Estimate }\end{array}$ \\
\hline 1 & $.307^{\mathrm{a}}$ & .594 & .578 & .4253
\end{tabular}

a. Predictors: (Constant), Resource Mobilization, Stakeholder Engagement

The findings reveal a positive correlation $(\mathrm{R}=0.307)$ between the independent variables combined and community economic development. In addition, the regression model explains $59.4 \%$ of the variation in the CBOs' ability to impact on the community's economic development as a result of variations in Resource Mobilization and Stakeholder Mobilization.

Table 7: ANOVA ${ }^{a}$

\begin{tabular}{llccccc}
\hline Model & & $\begin{array}{c}\text { Sum of } \\
\text { Squares }\end{array}$ & df & Mean Square & F & Sig. \\
\hline 1 & Regression & .492 & 4 & .123 & 1.095 & $.372^{\mathrm{b}}$ \\
& Residual & 4.720 & 42 & .112 & & \\
& Total & 5.213 & 46 & & & \\
\hline
\end{tabular}

a. Dependent Variable: Economic Development

b. Predictors: (Constant), Resource Mobilization, Stakeholder Mobilization 
Stratford Peer Reviewed Journals and Book Publishing

Journal of Public Policy \& Governance

Volume 5||Issue 3||Page 81-98 ||November||2021|

Email: info@stratfordjournals.org ISSN: 2616-8413

Table 8: Regression Coefficients ${ }^{\mathrm{a}}$

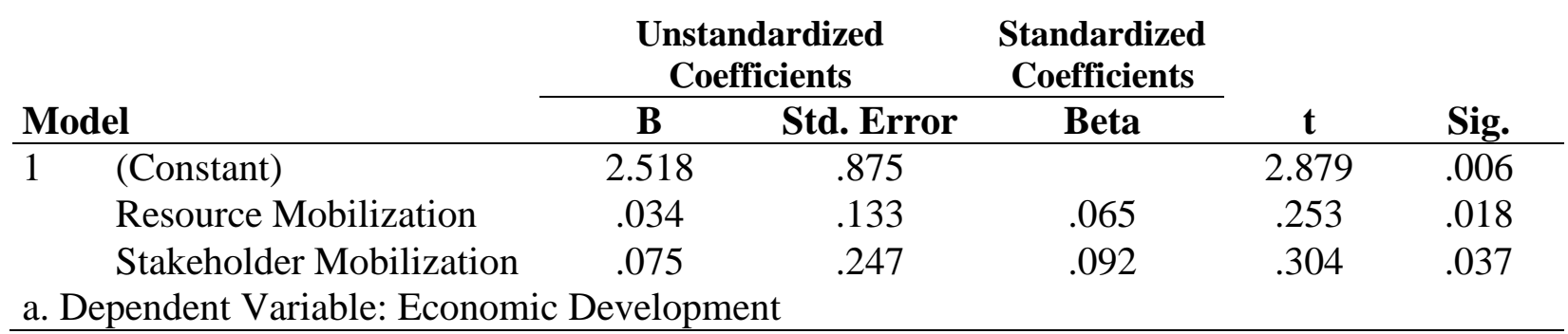

The regression analysis results show the predicted betas for the independent variables as: $\mathrm{X}_{1}-$ Resource Mobilization ( $\left.\beta_{1}=0.034\right) ; X_{2}-$ Stakeholder Mobilization $\left(\beta_{2}=0.075\right) ; X_{3}$ and a constant term of 2.518. Substituting the constant and the predicted values of the individual variable coefficients into the regression model yields:

$\mathrm{Y}=2.518+0.034 \mathrm{X}_{1}+0.075 \mathrm{X}_{2}$

\subsection{Discussions}

\section{Resource Mobilization and Community Economic Development}

The CBOs in Siaya County play a major role in mobilization of resources for economic development. Whereas many respondents agreed that their CBOs had adequate resources to effectively pursue economic development, some of the CBOs face resource constraints. In addition, the CBOs have enough capacity to develop quality proposals to attract resources and capitalize this strength to develop relationships with different institutions to permit effective resource mobilization. Moreover, the $\mathrm{CBO}$ members and officials who participated in the study opined that they have capacity to advocate for resources especially the devolved funds from the national and county governments. The study established a positive and statistically significant relationship $(r=0.256$; $\mathrm{Sig}=0.008)$ between the Resource Mobilization by CBOs in Siaya County and their contribution to community economic development.

\section{Stakeholder Mobilization and Community Economic Development}

According to the responses obtained, stakeholders are considered important to the CBOs which undertake economic development. For this reason, the CBOS have been accepted in their respective communities because they properly identify the appropriate stakeholders to support the implementation of their projects. In addition, through stakeholder mobilization, CBOs have managed to ensure inclusivity of the different groups in economic development activities. As a result, stakeholder mobilization has enabled the CBOs in Siaya County to identify and utilize available human resources in the community. Furthermore, the stakeholder mobilization initiatives have made it possible for the CBOs in Siaya County to easily resolve conflict on economic development at the community level. The study also indicated a positive and statistically significant correlation $(r=0.264$; Sig $=0.000)$ between stakeholder mobilization and community economic development which implies that enhanced stakeholder mobilization in community activities contributes to economic development. 


\subsection{Conclusion}

\section{Resource Mobilization and Community Economic Development}

The study has established that resource mobilization plays a vital role in project and program activities for the various CBO organizations. This study concludes that Resource Mobilization by CBOs in Siaya County enhances the organizations' contribution to community economic development. This is due to the fact that resources availability, quality and adequacy had a direct effect on projects and programs that are implemented by community based organizations. For this reason, it is important to diversify and upscale the initiatives aimed at increasing resource accessibility and use to address economic needs of the communities. Managers of community based organizations must build their resource mobilization skills and capacity to ensure that they properly mobilize resources to fund the activities of community based organizations. This will directly influence the effectiveness of programs and projects in the localities within which they are implemented.

\section{Stakeholder Engagement and Community Economic Development}

Findings of the study have already established that stakeholders have an important role in community based organizations and the activities that they perform within communities. Mobilization of stakeholders plays a critical role in community economic development. The mobilized stakeholders have an effect on how successful CBO projects and programs are in the communities in which they are implemented. In this regard, the CBOs in Siaya County have done well in working with the relevant stakeholders in implementing economic development projects. CBOs in Siaya County must ensure that they seek and mobilize various stakeholders to be part of the projects and programs that they are implementing. Though this, they will be able to enhance the effectiveness of the projects and programs that they implement.

\subsection{Recommendations}

\section{Resource Mobilization and Community Economic Development}

The CBOs in Siaya County which face acute resource constraints should tap into the huge resource mobilization potential to attract resources through responding to calls for fundable proposals. The findings already established that only a very small number of community based organizations mobilized their resources through proposal development. A training and capacity building on proposal development for the CBOs will therefore be beneficial to their resource mobilization initiatives. Where necessary, the CBO officials should seek help from professionals to enhance their capacities to write winning project proposals. These organizations should also come up with income generating activities to enable them generate passive income to fund some of their project activities.

\section{Stakeholder Engagement and Community Economic Development}

The CBOs in Siaya County have demonstrated a high level of efficiency in stakeholder engagement which is critical for acceptance at community level and successful project implementation. It would be important to also develop a profile of external stakeholders to be considered for sustainable partnerships towards enhanced economic development at the communities' level. Engaging with these external stakeholders will promote the effectiveness of program activities for the concerned CBOs. This in turn will directly affect community economic development outcomes for programs and projects that are implemented. 


\section{REFERENCES}

Akeju, D., Nance, N., Salas-Ortiz, A., Fakunmoju, A., Ezirim, I., Oluwayinka, A. G. \& BautistaArredondo, S. (2021). Management practices in community-based HIV prevention organizations in Nigeria. BMC health services research,2l(1), 1-10. https://doi.org/10.1186/s12913-021-06494-1

Bamberger, L. \& Cheema, L. (2010). Human Resource Management a Contemporary Approach, ( ${ }^{\text {th }}$ Ed.). Harlow: Prentice Hall.

Batti, R. (2014). Challenges Facing Local NGOs in Resource Mobilization. Humanities and Social Sciences, 2(3), 57 - 64. https://doi.org/10.11648/j.hss.20140203.12

Behnke, N. L., Klug, T., Cronk, R., Shields, K. F., Lee, K., Kelly, E. R. \& Bartram, J. (2017). Resource mobilization for community-managed rural water systems: Evidence from Ghana, Kenya, and Zambia. Journal of Cleaner Production, 156, 437-444. https://doi.org/10.1016/j.jclepro.2017.04.016

Boadi, D., \& Badu, E. (2021). Effects of community participation on Government-funded community-based development projects in Ghana (Doctoral dissertation).

Bourdieu, P. (2018). The forms of capital (pp. 78-92). Routledge. https://doi.org/10.4324/9780429494338-6

Bowen, G. A. (2009). Local-level stakeholder collaboration: A substantive theory of communitydriven development. Community $\quad$ Development, 36(2), 73-88. https://doi.org/10.1080/15575330509490176

Brunton, G., Thomas, J., O'Mara-Eves, A., Jamal, F., Oliver, S., \& Kavanagh, J. (2017). Narratives of community engagement: a systematic review-derived conceptual framework for public health interventions. BMC Public Health, 17(1), 1-15. https://doi.org/10.1186/s12889$017-4958-4$

Campra, M., Esposito, P., \& Lombardi, R. (2020). The engagement of stakeholders in nonfinancial reporting: New information-pressure, stimuli, inertia, under short-termism in the banking industry. Corporate Social Responsibility and Environmental Management, Early View, 1-9. https://doi.org/10.1002/csr.1896 https://doi.org/10.1002/csr.1896

Civera, C., De Colle, S., \& Casalegno, C. (2019). Stakeholder engagement through empowerment: The case of coffee farmers. Business Ethics: A European Review, 28(2), 156-174. https://doi.org/10.1111/beer.12208

Coleman, J. S. (1988). Social capital in the creation of human capital. American journal of sociology, 94, S95-S120. https://doi.org/10.1086/228943

Di Maddaloni, F., \& Davis, K. (2018). Project manager's perception of the local communities' stakeholder in megaprojects. An empirical investigation in the UK. International Journal of Project Management, 36(3), 542-565. https://doi.org/10.1016/j.ijproman.2017.11.003 
Dodoo, E., \& Kissi, E. (2021). Assessing the factors influencing the sustainability of communitybased projects in Ghana. A case of water, sanitation and hygiene (WASH) project (Doctoral dissertation).

Fole, S. W., Lixia, T., \& Guta, T. (2018). Sink or Swim? Survival Mechanisms Employed by Local Non-Governmental Organisations in Malawi: A Case from the Agriculture Sector Development Country Studies, 8(4), 73- 84. Available at https://core.ac.uk/download/pdf/234683324.pdf

Freeman, R. E. (2017). The new story of business: Towards a more responsible capitalism. Business and Society Review, 122(3), 449-465. https://doi.org/10.1111/basr.12123

Githinji, S. N. (2019). Factors influencing sustainability of community-based water projects in Kajiado County, Kenya: A case of Kajiado Central Sub-County [Doctoral dissertation, University of Nairobi].

Ihejirika, J., \& Ogbugo, E. (2018). Influence of Traditional Rulers in Resource Mobilization towards Community Development Projects in Rivers State. International Journal of Innovative Psychology \& Social Development, 6(2), 98-112.

Johansson, P. M., Eriksson, L. S., Sadigh, S., Rehnberg, C., \& Tillgren, P. E. (2009). Participation, resource mobilization and financial incentives in community-based health promotion: an economic evaluation perspective from Sweden. Health promotion international, 24(2), 177-184. https://doi.org/10.1093/heapro/dap008

John, H. N., Muturi, W., \& Nyang'au, A. (2017). Factors Influencing Strategies Adopted by Community Based Organizations in Kenya: a Case of Nyamira County. https://doi.org/10.9790/487X-1904028394

Kanyanya, L. O. (2014). Factors influencing sustainability of community water projects in Shianda division, Kakamega county-Kenya (Doctoral dissertation, University of Nairobi).

Kothari, C. R. (2014). Research Methodology: Methods and Techniques. ( ${ }^{\text {rd }}$ Ed.). New Delhi: New Age International (P) Limited.

Laurent, U., \& Ernest, S. (2021). Community Involvement in Planning and the Success of Rural Development Projects in Rwanda. Journal of Entrepreneurship \& Project Management, 5(2), 10-26.

Machalek, R., \& Martin, M.W. (2015). Sociobiology and sociology: a new synthesis. In: Smelser, N.J. \& Baltes, P.B. (eds.). International encyclopedia of the social \& behavioral sciences. ( $2^{\text {nd }}$ Ed.). Netherlands, Amsterdam: Elsevier https://doi.org/10.1016/B978-0-08-0970868.32010-4

Macharia, B. W. (2015). Factors influencing community participation in forestry conservation projects: a case of Kithoka-Twajai forest community based organization, Meru county Kenya (Doctoral dissertation, University of Nairobi).

Mapesa, J., Meme, J., \& Muthamia, O. (2020). Effect of community-based nutrition on infant nutrition and associated health practices in Narok, Kenya. African Health Sciences, 20(2), 724-734. https://doi.org/10.4314/ahs.v20i2.24 
Murungi, T. M. (2020). Determinants of Sustainability of Community Based Ecotourism Development Projects in Kenya. A Case of Northern Rangeland Trust Conservancy, Meru County (Doctoral dissertation, University of Nairobi).

Mutua, D. (2014). Influence of community participation stages on sustainability of communitybased water projects in Kenya: the case of Kiabaibate in Meru County [Doctoral dissertation, University of Nairobi].

Mwaura, S. N. A. A., Maina Kariuki, I., Kiprop, S., Muluvi, A. S., Obare, G., \& Kiteme, B. (2021). The impacts of community-based water development projects on rural poverty among small-holder farmers: Evidence from the Ewaso Ng'iro North Catchment Area, Kenya. Cogent Economics \& Finance, 9(1), 1882763. https://doi.org/10.1080/23322039.2021.1882763

Newing, H. (2011). Conducting research in conservation: a social science perspective. Routledge, England. https://doi.org/10.4324/9780203846452

Ojango, J. M., Oyieng, E. P., Gitau, J., \& Gachora, J. (2021). Training of trainers in communitybased breeding program for small ruminants in pastoral communities of Kenya, OctoberNovember 2020: Livestock Genetics Flagship activity report.

Papageorgiou, K., Singh, P. K., Papageorgiou, E., Chudasama, H., Bochtis, D., \& Stamoulis, G. (2020). Fuzzy cognitive map-based sustainable socio-economic development planning for rural communities. Sustainability, 12(1), 305. https://doi.org/10.3390/su12010305

Prieto, L. C., Wairimu, J., Ndinguri, E. N., \& Kungu, K. K. (2020). Promoting Sustainable Enterprise \& Human Resouree Development in Rural Kenya: A Cooperative Approach. Journal of Leadership, Accountability and Ethics, 17(5), 94-102. https://doi.org/10.33423/jlae.v17i5.3222

Rafique, Z., \& Khoo, S. L. (2018). Role of community-based organizations (CBOs) in promoting citizen participation. Internfvational Journal of Sociology and Social Policy. https://doi.org/10.1108/IJSSP-02-2017-0008

Siaya County. (2021). Siaya County Integrated Development Plan 201-2022. Siaya County. Available at https://siaya.go.ke/siaya-county-integrated-development-plan-2018-2022/

Sulkowski, A. J., Edwards, M., \& Freeman, R. E. (2018). Shake your stakeholder: Firms leading engagement to co-create sustainable value. Organization \& Environment, 31(3), 223241. https://doi.org/10.1177/1086026617722129

Tirivanhu, P. (2020). A realist assessment of the facilitation process for improving social accountability by community based organizations. Development Southern Africa, 37(6), 953-970. https://doi.org/10.1080/0376835X.2020.1761295

Velazquez, J. E. (2021). Climate Change-The Silent Pandemic: Identifying How CommunityBased Organizations (CBOs) Mobilizing Financial, Informational, and Resource-based Capital Through the COVID-19 Pandemic Can Inform Climate Change Planning and Response Efforts in Paterson, New Jersey (Doctoral dissertation, The Ohio State University). 
Walker, E. T., \& McCarthy, J. D. (2014). Legitimacy, strategy, and resources in the survival of community-based organizations. Social problems, 57(3), 315-340. https://doi.org/10.1525/sp.2010.57.3.315

Woods, H., Haruna, U., Konkor, I., \& Luginaah, I. (2019). The influence of the Community-based Health Planning and Services (CHPS) program on community health sustainability in the Upper West Region of Ghana. The International journal of health planning and management, 34(1), e802-e816. https://doi.org/10.1002/hpm.2694

World Bank. (2020). The State of Economic Inclusion Report 2021. World Bank. Available at https://www.worldbank.org/en/topic/socialprotectionandjobs/publication/the-state-ofeconomic-inclusion-report-2021-the-potential-to-scale 